\title{
Technology platforms in Russia: a catalyst for connecting government, science, and business?
}

\author{
Irina G Dezhina
}

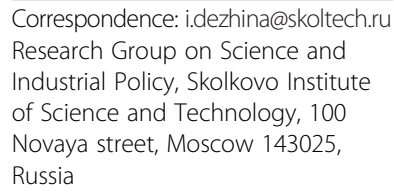

\begin{abstract}
The article analyzes a new instrument of Russian innovation policy - technology platforms. The reasons for their establishment are outlined based on the analysis of the innovation system in Russia. Comparisons with the European Union technology platforms, which served as blueprints for developing similar structures in Russia, are provided. Russian platforms are found to suffer from the government micromanagement. More detailed analysis is provided through three case studies of selected technology platforms specializing in different representative economic areas. The results of these studies demonstrate that Russian technology platforms are still far from being effective communication instruments. The platforms received inadequate federal support at the initial stages of their development, which eventually affected their performance. Nevertheless, the first steps have been undertaken to create expert communities in important economic areas. The article suggests directions for further development of technology platforms, such as expanding a palette of stakeholders and conducting two-way monitoring - both of platforms' performance and government measures aimed at their development.
\end{abstract}

Keywords: Technology platforms; Innovation policy; Research and development; Instruments; Russia; European Union

JEL classification: $\mathrm{O} 31 ; \mathrm{O} 32 ; \mathrm{O} 38$

\section{Multilingual abstract}

Please see Additional file 1 for translations of the abstract into the five official working languages of the United Nations and Portuguese.

\section{Background}

Technology platforms represent a new instrument of federal-level policy in Russia for connecting major actors of the innovation system. In this area, Russia trails not only the developed, but even the Brazil, Russia, India and China (BRIC), countries. The innovation system's major components still remain disconnected, so that, in effect, no real 'system' is in place.

Technology platforms (TP) were initiated at the government level in 2010 with an overall goal of developing promising commercially viable technologies. In addition, TPs were expected to create favorable conditions for their member companies by (strategy for innovation development 2011):

\section{Springer}

(c) 2014 Dezhina; licensee Springer. This is an open access article distributed under the terms of the Creative Commons Attribution License (http://creativecommons.org/licenses/by/4.0), which permits unrestricted use, distribution, and reproduction in any medium, provided the original work is properly credited. 
- Providing access to new resources for research and development (R\&D),

- Helping to define priority directions for the country's economic development,

- Assisting in the development of new technology regulations and standardization,

- Optimizing business planning (because member companies include both producers and consumers of new technologies),

- More effective use of resources via outsourcing,

- Developing international cooperation.

Today, $34 \mathrm{TPs}^{\mathrm{a}}$ are functioning. The concept of the TP was adopted from the example of the European Union (EU). The EU TPs were first implemented about 10 years ago, initially as an instrument for negotiations of inter-country interests in development of certain technologies. These TPs served to work out strategies for new research and technologies. The strategies then formed a basis for programs and projects within the EU framework programs. The major stakeholders of EU TPs include representatives of research organizations and universities, industry, government bodies, financial institutions (banks and investment funds), venture funds, and civil society representatives. However, commonly, large companies also initiated TPs.

This article benchmarks the Russian experience against the EU practice, discusses details of TP implementation in Russia, and suggests directions for their more effective use. The study is based upon the literature review (including policy documents), interviews with government officials responsible for implementation of TP in Russia and the EU, and three case studies of Russian TPs. The case studies assess the self-perception of the TPs' coordinators in terms of motivation, state of the art, and potential paths for development.

\section{State of the art}

The Russian innovation system is still largely influenced by the Soviet legacy. In the Soviet Union, the R\&D system, including industry, was government-owned and controlled. This system consisted of three main pyramids in organizational and institutional terms, which can be called the 'university system,' the 'academy of sciences system,' and the 'industrial and defense ministry system' (Graham and Dezhina 2008). The university system was predominantly a teaching institution, whereas the institutes under the auspices of the Academy of Sciences performed most of fundamental research. The industrial and defense ministerial system was primarily involved in applied research, although it also contributed some fundamental research (just as the Academy of Sciences system performed some applied research). Military research played a large role, not only in this industrial-defense pyramid, but also at the universities and the academy institutes. The military was given about $75 \%$ of all resources (Saltykov 1997).

In modern Russia, the R\&D sector is still largely owned and financed by the government. The latest data (for 2012) show that $70.9 \%$ of all the R\&D work is performed by the government-owned institutions/industry and only $11.5 \%$ is conducted by private organizations, the latter indicator increased slightly since 2000 (71.7\%, government; 9.5\%, private) (Science Indicators 2014). The rest of R\&D is conducted in organizations of mixed property. Russian industry contributed $27.2 \%$ of the national $R \& D$ expenses, which is in decline compared with the year 2000 (33\%) (Science and Technology Indicators 2013). In the developed countries, this percentage is much higher (varying from 45\% in UK to 66\% in Germany) (OECD 2010; OECD 2012). 
Therefore, government continues to be at the center of the Russian triple helix. In fact, the structure still resembles a 'pyramid' with linkages between the government and R\&D organizations and the government and industry, but weak interactions between the $R \& D$ sector and industry; that is, one major link of the triple helix is largely missing.

Many elements of the Russian innovation system have been created during the last 15 years; however, these developments failed to produce an innovation boost (Dezhina 2010). The failure is caused by a disconnection between $R \& D$ organizations and industry in terms of cooperation in $R \& D$ between companies and universities, outsourcing of research by industry, and cooperation in development of innovative products. Table 1 compares the state of linkages in innovation systems in Russia to those in both developed and BRIC countries.

At present, the Russian innovation system resembles an unfinished construct with nearly all the elements in place, but still remaining unassembled. This situation is mainly the result of erratic government policies, with scant monitoring of measures once they are started, short planning horizons, and projects, sometimes abandoned even before their completion deadlines. Government measures are often situation-based rather than carefully planned with examples found in various innovative infrastructure projects, such as special economic zones (SEZ). The SEZ project has been initiated following the study of the Chinese experience, but after several years, Russian government agency responsible for development of SEZ was closed, leaving a number of newly created zones only partly functioning. The government always expects quick results, which is rarely possible (Dezhina 2008). According to numerous studies of technological innovations, at least 5 to 7 years are required for initiatives to yield noticeable positive outcomes.

By the end of the 2000s, the government realized that horizontal linkages between universities, R\&D organizations, and industry are important for innovative development and should be encouraged. Failures to build a well-functioning innovative system were attributed to inadequate horizontal connections rather than to the style of decisionmaking and governance at the state level. The government saw TPs as a solution for providing these linkages.

Since the first TPs in Russia were created in 2010 to 2011, their effectiveness has not yet been studied. Several publications touch upon the Russian TP (Luksha 2010; Shelyubskaya 2011; Shelyubskaya Shelyubskaya 2012), but these are mostly related to analyses of the adaptability of the EU experience. In contrast, in the EU, TPs have been evaluated at the government level (Evaluation of the European technology platforms 2008) and this is an ongoing process (European technology platforms 2012).

\section{Methods}

The present analysis relies upon the three case studies of Russian TPs. These studies have been commissioned by the Russian Ministry of Education and Science with a

Table 1 Linkages in innovation systems, according to the World Bank's 'Knowledge Economy Index' (measured on the scale from 1 to 7, data for 2010)

\begin{tabular}{|c|c|c|c|c|c|c|c|c|}
\hline Indicator & USA & UK & Germany & France & Brazil & India & China & Russia \\
\hline Cooperation of companies and universities & 5.8 & 5.6 & 5.2 & 4.0 & 4.3 & 3.7 & 4.6 & 3.7 \\
\hline Presence of value chains & 5.1 & 5.5 & 6.3 & 5.7 & 3.7 & 3.9 & 4.0 & 2.6 \\
\hline
\end{tabular}

Source: http://info.worldbank.org/etools/kam2/KAM_page3.asp. 
request to determine how the instrument of the TP is applied in practice. The three platforms were selected in industries that exhibit distinct levels of technological development and innovation: extraction of mineral resources, biotechnology, and radiation technology (a part of the nuclear industry). The resource-extracting industry is dominant in Russia and potentially could drive domestic innovations (currently, it mainly adopts/imitates foreign technologies). By contrast, biotechnology, which is in the mainstream of modern economic development, remains underdeveloped in Russia. Finally, the nuclear sector represents industries that have a high technological potential, which has been accumulated but still not fully utilized in Russia.

All three platforms were created in 2011. The total number and composition of participants in the selected TPs differ markedly. At the time of the first survey (fall, 2012), the TP in the resource-extracting industry attracted 82 participants, from which $43 \%$ represented industrial enterprises (production and services). R\&D organizations and universities together accounted for 51\%. The TP in biotechnology included more than 150 organizational participants, from which more than half were research organizations and universities (54\%), while industrial enterprises constituted 37\%. Finally, the TP in radiation technologies included 80 participants, from which $35 \%$ were small and medium innovative companies and $42 \%$ comprised R\&D organizations and universities. Thus, while all three platforms incorporate a significant fraction of participants from universities and R\&D institutes, the resource-extracting TP is dominated by large companies, whereas the radiation TP has significant representation from small innovative enterprises. This could influence individual TPs' goals and assessment of their achievements depending on their differing motivations.

Only the Biotechnology TP cooperated with the similar-theme EU platform, "biobased economy'. The resource-extracting TP has not established any contacts with the respective European platforms, whereas the radiation TP has no EU analogs.

Unlike many other Russian platforms that remain passive, the three selected TPs are working actively; that is, they developed strategic plans, created networks of interested stakeholders, and participated in conferences and trade shows representing technology platforms.

The interviews were conducted with the representatives of coordinating organizations of the selected TPs. The coordinating organization accumulates all information about the TP activities and can provide a broad view on the platform accomplishments and problems. In addition, separate interviews were conducted with representatives of TPs, usually those who constituted a majority of a given TP (i.e., universities, industrial enterprises, or academy institutes). The interviews took place in the fall of 2012 and were completed with the follow-up questions in the fall of 2013. These were unfocused, approximately 2-h interviews based on a set of key framework questions. New themes that appeared occasionally during the interviews were included in subsequent questionnaires.

\section{European versus Russian technology platforms}

Russian TPs differ from those in Europe. The EU follows a bottom-up approach, whereas Russia adopts its traditional path of top-down initiating and regulation. The Russian government is a major creator and facilitator of TPs, which are seen not only 
as a means of communication among actors of the innovation system but also as experts for designing national industrial policy.

Large companies are not as active in Russian TPs as they are in the European analogs. The TP key participants in Russia are universities and government research institutes, whose major focus is on developing R\&D projects and on search for their financial support.

The European Commission sets merely recommended directions of activity for TPs (strengthening the role of European technology platforms 2010). In Russia, the platforms are obliged to perform certain functions (like analysis of policy documents) by the government. At the same time, unlike their European counterparts, Russian TPs receive no initial financial support. As a result, the Russian platforms started to function less effectively. Frequently, Russian TPs have had difficulties even with defining the priority R\&D areas for their activities (Kozak 2012).

Interestingly, a consensus on defining positive outcomes of the platforms' operations is still missing in both the EU and Russia. The result of platforms' work can be measured by the existence of a 'vision', outlined in strategic plans for development and in new collaborative R\&D projects that were initiated by members of TP. The EU experience demonstrates that over time, some TPs evolved into more formal partnerships with industry (so-called 'Joint Technology Initiatives'), while others have stagnated. These processes reflect natural development of TPs in Europe, where these platforms are self-organized structures, free of direct government management. The major differences between the EU and Russian TPs are summarized in Table 2.

\section{Findings from case studies and discussion}

The three platforms selected for the case studies differ by the type of key stakeholders (though R\&D organizations and universities dominate in all cases), level of development of strategic documents and plans for their realization, and the ability to attract external

Table 2 Technology platforms: EU versus Russia

\begin{tabular}{|c|c|c|}
\hline Characteristics & EU & Russia \\
\hline $\begin{array}{l}\text { Formative } \\
\text { principle }\end{array}$ & Bottom-up & Top-down \\
\hline \multirow[t]{3}{*}{ Goals } & 1) Coordinating interests of EU countries & 1) Creating new technologies \\
\hline & $\begin{array}{l}\text { 2) Linking fundamental research and practical } \\
\text { applications }\end{array}$ & 2) Attracting additional resources for $R \& D$ \\
\hline & 3) Synergy among major stakeholders & $\begin{array}{l}\text { 3) Improving legal regulations in } R \& D \\
\text { and innovation }\end{array}$ \\
\hline \multirow[t]{4}{*}{ Tasks } & Developing strategic plans and roadmaps & Developing strategic programs \\
\hline & Marketing of ideas & $\begin{array}{l}\text { Developing programs for disseminating } \\
\text { new technologies }\end{array}$ \\
\hline & & Educational activities \\
\hline & & Expert functions for the government \\
\hline Funding & State, private, self-financing & $\begin{array}{l}\text { Government financing (planned), } \\
\text { private (planned), self-financing }\end{array}$ \\
\hline \multirow[t]{2}{*}{ Government role } & Promoting platforms concept & Participating in governing the platforms \\
\hline & $\begin{array}{l}\text { Limited financial support of } \\
\text { operational activities }\end{array}$ & $\begin{array}{l}\text { Attracting platforms as experts monitoring } \\
\text { platforms' activities }\end{array}$ \\
\hline
\end{tabular}

Source: compiled by the author.

Russian TPs still face an uncertain future, not only in financial terms, but also because it remains unclear which of them will survive and which will be closed by the government. 
funding for R\&D. For example, the Biotechnology TP has already developed a strategic program, the radiation TP had conducted a deep foresight, while the TP for the resourceextracting industry only started to develop a strategic program.

All Russian TPs must implement several tasks assigned to them by the government, including:

- Selection of R\&D projects;

- Search for budgetary and non-budgetary sources of support;

- Assistance to companies in developing high-tech products;

- Improvement of legislation for research and innovation;

- Assistance in development of educational initiatives.

Table 3 summarizes the performance of the three selected TP in addressing these tasks.

Case studies have been conducted to clarify the following issues:

1. Motivation for an organization to participate in a TP;

2. Sources of funding attracted by the platforms;

3. Scope of expert functions implemented by a TP;

4. International activity;

5. Criteria of effectiveness set by platform coordinators.

\section{Motivation of organization to participate in technology platforms}

The major motivation for an organization to become a member of a TP is either hope for easier access to federal funds for its $R \& D$, or the opportunity to participate in the development of government regulations in the areas of technical standards, certification, intellectual property rights protections, etc.

'All organizations were willing to be in the platform; there was optimism that this is a new instrument supported by financing. They were thinking that they will get additional financing for RED and also that they will influence the state in terms of choice of directions for further development. Another motive was to show that in the resource-extracting industries there may be high-tech developments' (Head of Coordinating Committee, TP in resource-extracting industry, September 25, 2012)

Table 3 Tasks implemented by the surveyed technology platforms

\begin{tabular}{|c|c|c|c|}
\hline Task & $\begin{array}{l}\text { Biotechnology } \\
\text { platform }\end{array}$ & $\begin{array}{l}\text { Radiation technologies } \\
\text { platform }\end{array}$ & $\begin{array}{l}\text { Resource-extracting } \\
\text { industry platform }\end{array}$ \\
\hline Attracting budgetary sources for $R \& D$ & Yes & Yes & Yes \\
\hline Attracting non-budgetary sources for R\&D & No & No & No \\
\hline Interacting with state corporations & No & Yes & Yes \\
\hline Expert evaluation of government decisions & Yes & Yes & Yes \\
\hline $\begin{array}{l}\text { Assisting in development of educational } \\
\text { activities }\end{array}$ & No & No & No \\
\hline International activity & Yes & Yes & No \\
\hline Interacting with clusters & Yes (foreign) & Yes & No \\
\hline
\end{tabular}

Source: compiled by the author, based on the interviews with the TP coordinators. 
Nevertheless, the views of the three platforms are slightly different. The resourceextracting industry platform underlined the importance of a more active involvement of companies in lobbying their interests with the government, and they see platforms as a lobbying instrument. TPs are also seen as a stimulus for companies to invest in $\mathrm{R} \& \mathrm{D}$. According to the interview, currently, the Russian oil companies take little interest in innovations because they acquire most of technologies abroad. Better connections with universities and $R \& D$ institutes may change the situation and persuade companies to look more carefully at domestic resources.

The TP in radiation technologies stresses the importance of a unified effort. In their field, many small companies are disconnected from each other. Therefore, the platform is expected to consolidate expert opinions and select priorities, thereby stimulating mergers and acquisitions, which may prove beneficial for this industry. They also think that the platform is a tool for creating small firms.

'There were two major motives. First was consolidation of efforts. There are many small teams and each of them thinks that it is competitive. But we are driven by the market, and merging and acquisitions are unavoidable. There are few good companies, and the platform may ensure their selection. The second motive was that the platform is a way to interact with the state. Platforms represent a consolidated opinion about financing, about value chains' (a representative of the development institute of the Russian Federation, coordinating the platform's activity; TP in radiation technologies, September 14, 2012).

In contrast, the biotechnology platform indicated the lack of enthusiasm among the organizations working in this area about participating in the platform. Therefore, this TP is mainly represented by the academy institutes and universities, which are more responsive to the government initiatives hoping to obtain additional funding from the federal budget. One of the main goals for this platform is to form a biotechnological market in the country; the goal is highly, if not too ambitious, considering the nearly non-existent biotechnology industry in Russia.

The overall self-perception of platforms' stakeholders continues to be individualistic, with each party having its own agenda and being reluctant to cooperate with others. The stimuli for TP members to develop and promote mutual interests are still missing.

\section{Financial resources attracted by platforms}

The TP for the resource-extracting industry has received federal funding for its $R \& D$ projects, but was unable to attract any private sources despite the participation of several significant industrial companies. The platform coordinators indicated that the companies are reluctant to support pre-competitive research - an attitude that is consistent with the more general trends typical for large Russian companies in this field, which prefer acquiring licenses for foreign technologies to developing their own 'know-how'. The platform that specializes in radiation technologies represents a special case from the financial point of view because it relies upon the funds supporting small innovative companies. Such companies are active members of this platform and they managed to secure federal funding for their R\&D. At the same 
time, this platform has no non-budgetary funding. The representative of coordinating organization indicated that large companies are not willing to invest in R\&D:

"...There are solvent private companies - they are ready to finance their own RED but they are not ready to outsource RED' (September 14, 2012)

Finally, the biotechnology platform was not able to attract any funding and, therefore, all the organizational work was voluntarily conducted by the organization coordinator. In summary, the mechanisms of non-budgetary support for the TP have not started to function yet. In the absence of the government support for the organizational work, the member companies were reluctant to fund the $R \& D$ projects initiated by the platforms.

\section{Scope of expert functions implemented by platforms}

All the surveyed platforms participated in various expert groups and in analytical work performed at requests of the government bodies. Despite limited federal support, the TPs were very responsive to such requests; apparently, this willingness to cooperate is a reflection of the government dominance and control:

"The Ministry and others want something all the time, and their request is always - 'do it yesterday'. We (platform) have to do it very fast, but good experts are always busy. Therefore we respond to the extent we can. ... Every agency wants something... and always for free...' (Head of commission on international cooperation, TP in biotechnology, September 19, 2012)

The TP in the resource-extracting industries was involved in the development of new tax exemptions; two other TPs did not specify their tasks but cited continuing requests from the government to conduct expert evaluation of projects/documents.

\section{International activity}

Two platforms out of three have recognized international activity as an important component of platform functioning. The TP in radiation technologies managed to attract foreign specialists to their board, which helps to develop a modern vision for the industry. Yet, this TP does not cooperate with EU platforms, citing the absence of an appropriate EU TP in the field. The TP in biotechnology is one of the most internationally involved but only in academic research, not technological innovations. The international cooperation started long before this platform was created, and therefore it simply inherited the ties that existed between the academy institutions and their international partners. The platform coordinators' plan to transfer technologies to Russia because the domestic industry is underdeveloped compared to the European countries:

«...Real transfer of technologies will be from abroad to us, because here ... cutting-edge industrial technologies are unknown. We are lacking behind completely' (Head of commission on international cooperation, TP in biotechnology, September 19, 2012). 
The TP in the resource-extracting industry is not involved in international cooperation as an entity. However, some of its leading member companies have well-developed ties with foreign partners:

In the EU there is a platform on mineral resources but it is not functioning. They have a web-site, they have a program for development, but they died. ...First, because of the crisis, and second, because there are not many resources in Europe. For us, there is an interesting partner - Australia. But we are not in touch at the platform-to-platform level. Cooperation is at the level of organizations-members of platforms' (Head of Coordinating Committee, TP in resource-extracting industry, September 25, 2012).

\section{Criteria of effectiveness set by platform coordinators}

The coordinating organizations of TPs have not yet developed a coherent set of indicators for measuring TP success. Apparently, the strategic plans that are being developed by the platforms do not even discuss self-assessment. In a predominant number of interviews, the respondents only improvised on what might be considered as criteria for measuring the effectiveness of TP. A number of joint projects with industry initiated by the platforms and the amount of additional funding have been repeatedly suggested as plausible indicators of success. Another indicator is the type of stakeholders. Each platform has a different view of this issue. The TP in the resource-extracting industry deems it important to attract large companies and to initiate more public-private partnerships. The TP in radiation technologies prefers to force the commercialization of R\&D results through interactions with small companies.

The biotechnology platform suggested yet another criterion - a volume of funding attracted through membership fees. None of the platforms mentioned criteria that would measure establishment and /or development of new linkages within a TP.

\section{Conclusions and policy implications}

Technology platforms, as a new Russian government initiative to stimulate communications among certain industries, rely on foreign experience. However, specifics of the Russian innovation system, which is largely funded and micromanaged by the government, affect the design of new policy measures. At present, the platforms cannot serve as communication instruments because their participants remain disconnected with low stimuli for cooperation.

Overall, the Russian innovation system appears to be stubborn to changes, which are hindered by path dependency and belief in exclusively federal support. Evidently, the entire system is incapable of functioning according to the schemes inherited from the Soviet model, and the needed natural demand for cooperation among various parties involved in technological innovation is lacking. Nevertheless, one positive aspect of recent developments is in the very attempt of the government to reverse the situation and, by introducing TPs as a communicational instrument, to bring stakeholders in the Russian innovation system closer to each other.

For better results, the palette of stakeholders in platforms should be extended to banks, venture companies, and other financial institutions. This would help to define the perspective and commercially attractive projects. A sensible approach at the federal 
level would be to let the platforms operate for a certain period of time before assessing their chances for survival; potentially, the 'survivors' could suggest new approaches to networking. In Europe, small innovative enterprises are important beneficiaries of the platforms. Yet, in Russia, the role of small businesses is insignificant. Supporting small companies using such mechanisms as loans, subsidies, and state insurance agreements appears to be an important component of the platform's success.

Finally, the mechanisms for monitoring technology platforms remain to be developed. The two aspects of major importance are monitoring (1) of the platforms' performance and (2) the effectiveness of the government's measures regarding the platforms. The evaluation has to be two-way to strengthen the performance of both the TPs and government agencies.

\section{Endnote}

${ }^{\mathrm{a} D a t a}$ for May 2014.

\section{Additional file}

Additional file 1: Multilingual abstracts in the five official working languages of the United Nations and Portuguese.

\section{Competing interests}

The author declares that she has no competing interests.

\section{Acknowledgements}

This work was supported by the Ministry of Education and Science of the Russian Federation and the Russian Foundation for Technological Development.

Received: 6 April 2014 Accepted: 1 July 2014

Published online: 28 October 2014

\section{References}

Dezhina I (2008) Government regulation of science in Russia. Magistr publisher, Moscow (in Russian)

Dezhina I (2010) Russian science policy during the crisis. Sociology of Science and Technology 1:67-88 (in Russian)

European Technology Platforms-2020 (2012) Draft strategy. European Commission, Brussels. November 5, 2012. http://www.industrialsafety-tp.org/filehandler.ashx?file=12346 Accessed 18 December 2013

Graham L, Dezhina I (2008) Science in the new Russia: crisis, aid, reform. Indiana University Press, Bloomington

Kozak S (2012) Technology platforms as basis for innovative development. 14.09.2012. Trade-Industrial Gazette. http://tpp-inform.ru/analytic_journal/2708.html Accessed 18 December 2013

Luksha O (2010) European technology platforms: possibilities to use foreign experience for creation of new instrument to support innovative development of Russian economy. Innovations 9:34-41 (in Russian)

OECD Science (2010) Technology and industry outlook. OECD, Paris

OECD Science (2012) Technology and industry outlook. OECD, Paris

Saltykov B (1997) The reform of Russian science. Nature 388:16-18

Science and Technology Indicators in the Russian Federation (2013) Data book. National Research University - Higher School of Economics, Moscow

Science Indicators (2014) Data book. National Research University - Higher School of Economics, Moscow

Shelyubskaya N (2011) Technology platforms - mechanism for development of branch strategy and cooperation (EU experience). In: Pivovarov Yu et al. (ed) Russia: tendencies and prospects for development. Yearbook, part 1. INION RAS, Moscow, pp 733-739

Shelyubskaya N (2012) European technology platforms - from development of branch research priorities to clusters. Innovations 9:51-57. in Russian

Strengthening the role of European technology platforms in addressing Europe's grand societal challenges (2010) Report of the ETP expert group, EC DG for research. Brussels. ftp://ftp.cordis.europa.eu/pub/etp/docs/faindustrialresearch-b5-full-publication-rp_en.pdf Accessed 18 December 2013

(2008) Evaluation of the European technology platforms. final report. ftp://ftp.cordis.europa.eu/pub/technologyplatforms/docs/evaluation-etps.pdf. Accessed 18 December 2013

(2011) Strategy for innovation development till the year 2020. www.rg.ru/pril/63/14/41/2227_strategiia.doc. Accessed 18 December 2013

doi:10.1186/s40604-014-0006-x

Cite this article as: Dezhina: Technology platforms in Russia: a catalyst for connecting government, science, and business? Triple Helix 2014 1:6. 